Мцаденко С. Саџак ${ }^{1}$

Универзитет у Бањој Ауци

Фимолошки факултет

\title{
СРПСКИ НАРОД, ЦРКВА И ЗЕМЉАУ ТУРСКО ДОБА (ИСТОРИЈА, ЗАПИСИ, КЊИЖЕВНОСТ)
}

Апстракт: Основна намјера у овоме раду била је да се класификују и представе главне теме српских страдағь у тзв. турско доба, а то су: мученичке судбине појединаща, страдане народа (одвођене дјеще у ропство, исламизащија и друго), рушетье иркава и манастира и, на крају, расељавате становништва и опустошетье земаза. Међутим, спечифична предметна грађ а као и различити извори на основу којих је ова тема посматрана наметнули су још један истраживачки циз: да се успоставе односи (па и могући закони трансформачија) између историјских догађаја и чиғеница, итурих монашких записа и ријетких хроника о тима, а онда и литерарних текстова/книжевних дјела која су настајала на тиховом предлошку.

Кључне ријечи: турско доба, страдаға и нащионална филологија, историјски извори, стари српски записи, смисао къижевности.

\section{УвоА}

Појам турско доба, период оА 15. Ао 19. вијека, када наА хришћанским народима на Бамкану вцадају „невјерни и трикмети Агарјани”, у колективној свијести код Срба зазива затамњена сјећања на „скрбна и бесудна времена”, на вијекове трпьења и невоља, на многа и велика страдања „сиротиње раје”, а онда и на приче о хајдуцима и осветама, о побунама и сеобама.

Историјски извори о том периоду двојаке су природе. На једној страни су документа и исправе, подаци и пописи (дефтери) који говоре о владарима и политикама, о војсковођама и ратовима, о Аруштву и привреди. ПореА ове грађе, која је мамобројна, постоји и јеАна другачија, бројчано и тематски богатија и саАржајнија, а која се због великог уАјема Аичног и осјећајног може 1.mladenko.sadzak@flf.unibl.org 
Младенко С. Саџак

назвати и литерарном. Она је настајала и сачуваца се у монашким записима, на маргинама $и$ тургијских књига и црквених списа, у манастирским библиотекама, или пак у народној пјесми, предању и мегенди, одакце је нацазима своје путеве ка нашој старијој или новијој писаној књижевности.

У тим нашим старим записима и књижевним текстовима тематизују се, између осталог, приче о ьудима и догађајима, о мученичким судбинама појеАинаца, о рушењима цркава и манастира, скрнавьењима хришћанске вјере, о исламизацији, отмици дјеце, расељавању народа, опустошењу земаља, о глаАним годинама, пошастима и сл. (Панић-Суреп 1963).

Непостојање или нецјеловитост историјских извора, бар што се тиче историје Срба у Босни, присиьава историчаре да у својим радовима користе и ову грађу, премда се она по правилу не сматра поузданом за проучавање прошлости. С Аруге стране, бројчано и тематски веома богата и садржајна, она ипак упућује на могућу (мање ими више одрживу) реконструкцију догађаја из прошиости.

Као примјер може послужити историја српских манастира у сјеверној Босни и Крајини - о њима се поуздано скоро ништа не зна: ни ко их је подизао, ни када су настајали, ни ко их је осликавао; не постоје ктиторске повеье, Аародавнице, хронике, па ни датуми њиховог опустошења. Тек покоји сачувани запис, једно ими два мокална предања (која се, као по правику, вежу за Немањиће), можАа и помен у неком језичком изразу или пјесми, и то је све. ОА њих су нам остала само имена: ГАоговац (коА Шипова), Трескавац (коА Рибника), Пецка (на извору Сане), Киисина (између Санског Моста и ПријеАора), Голубић, Хргар и Рачић (код Бихаћа), Грчки манастир (између Бјелаја и Босанског Петровца), Панађур (код Колунића), Висућица (код Шиповьана), Градина (код Грахова), Ђурђевац (у Кнежопову), Мимошевац (код Приједора), УАрим (ики Гостовић, по истоименој ријеци пореА Завидовића), Аетлак (коА Аервенте), Гнионица (код Босанског Брода)...

Јеромонах Герман Јовановић је још 1891. године, немајући извора за писање историје Воведенског манастира Гомионице, устврдио:

Не знам, да Аи има што теже, него код нас у Босни писати о прошлости нашој, из онијех вјекова, које протаворисмо у умној метаргији и неповољним политичким приликама. Тешко се данас повратити натраг неколико стољећа и историјски нешто доказати, о чему поузданих извора немамо. Сјај културе и вијековима течене наше тековине - историјске споменике, задужбине и књиге староставне, пламен је и непросвећена осветничка рука уништика (Јовановић 1891: 45-47). 
И управо на тим мјестима историјских затамњења, када непостојање извора ствара празнину, појављују се они посвећенички монашки записи који, мичећи на изненада нађена многоцјена бисерова зрна, преАставьају вриједна и значајна свједочења, и то не само о појединим људима и приликама него и о нашој свеколикој национацној прошиости.

\section{Записи}

Питање о томе гАје је граница између историје и књижевности, оАносно по чему се (по којим мјерилима) одређени запис посматра као историографска чињеница ими пак као митерарни текст, Аискутабимно је, поготово што се поједини оА њих могу тумачити и метонимијски - као Аио за цјелину, односно као појединачни исказ који представља опште мјесто у ширем Аруштвеном и историјском контексту.

Неријетко записи прате стварне историјске догађаје, ратове, законе, Аруштвена дешавања, владаре:

Пак мета 1713. идоше Турци на Црну Гору, робише и палише, змо чинише много” (Стојановић 1982: бр. 5344). ИАи: „Године 7223 (1715) идоше Турци на море на Котаре, и бише град Сињ много Ани и не возмогоше узети (Стојановић 1982: бр. 5346).

Када је 1565. године наслиједио Сулејмана Величанственог, султан Селим II је пооштрио односе према балканским хришћанима и донио је одлуку да се њихова црквена и манастирска добра јавно распродају루 четири године послије у јеАној српској рукописној књизи наимазимо на овај запис:

Тагда бист велика биједа [под] МехмеА-пашом ${ }^{3}$ и царом Селимом: проАадоше цркве христијанскје, и бист гоненије веље, и биједа јакова нест бима од вијека, амин (Стојановић 1982: бр. 51504).

Прва реченица записа који слиједи говори о поразу Турака под Сиском 28. јуна 1593. године, а у потоњој се разоткрива тешки удес који је у позадини тог рата задесио „род христијански”:

\footnotetext{
${ }^{2}$ „Који манастир није био у стању да откупи своје земње, стављене су на јавну распродају, а ако их је откупио, повећани су на те земье феудални и државни терети. О овоме има спомена и у метописима Аруге половине XVI века, а Ар Бранислав Ђурђев нашао је за ово и потврду у дефтерима сремског санџака тога доба. И у Београду су порушене тада неке цркве и оА њих је Мехмед-паша Соколовић дао саградити свој безистан и караван-сарај” (Чубримовић 1960).

${ }^{3}$ Соколовићем.

${ }^{4}$ Запис у рукописној књизи манастира Ораховице из 1569. године.
}

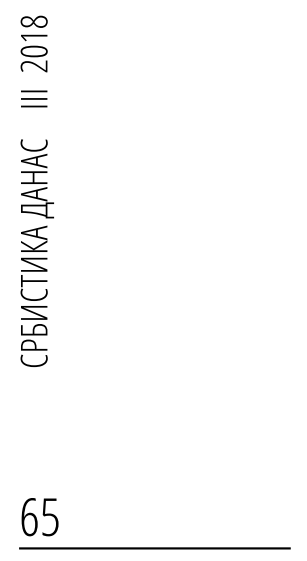


Младенко С. Саџак

В тожАе мето погибе Хасан паша са множством Агарјана на ријеци Купи под градом Сиском. Ох, ох! Биједа у то вријеме роду христијанскому, јако крити се у земьу живем в ти Ани (Стојановић 1982: бр. 8495) [у значењу: јеАино ако би се у земьу сакрили, преживјели би те Аане. Прим. аут.].

У многим записима наилазимо на недаће - болести, намети, насицништва и гладне године - које су и иначе пратиле ратове; у јеАном из 1608. године, о глади у Зети, земьи Ивана Црнојевића, грешни монах Авакум, „којему је отачество гроб, а богатство гријех”, казује: „И у то ьето бист крепки глаА, јакоже чловеком оА својих живот Аишити се. Ох бијеАа, ох туга, ох скрб, у то ьето оА проклетих чеда агарјанских на христијански род! Ох, ох, ох!" (Стојановић 1982: бр. 970).

ПонекаА су ти записи о гмади прости и јеАноставни, као нпр. овај: „1686. ьета би глаА у Босни" (Стојановић 1982: бр. 5710); а понекаА су такви Аа се не може повјеровати у њих: „1690. би глаА и тешкоћа у Босни... И то ьето једоше чловеци пасје месо, и коњско, и чцовеченско, пуно многе нечистоће” (Стојановић 1982: бр. 5712).

Један запис из манастира Сретења биьежи да се 1595. године „подиже рат Турком с Угри”, и да тада би „истребљење и биједа црквама и свештеницима и хришћанима оА Исмаимићана у српској земьи и по другим крајевима, (и) безбројна убиства и запуштења светих обитеьи" (Стојановић 1982: бр. 8686).

Историчар Ђоко Слијепчевић објашњава како су та страдања народа, цркава и манастира „бима директна последица кретања војске на ратишта и са њих...” Он наводи један запис из 1599. године у којем се каже: „Ах, каква беше тада туга у тој земьи. Аа то, укратко, кажем: палили су села и градове, опустошаваци многе цркве, крали свете иконе, скрнавили и раскопаваци света места и у ьуто зимње доба скудаху ьуде до гола и бијаху их; неке, голе, везане коњима за репове, вуцијаху, друге, опет, сецијаху ими стрељаху. И није било места гАе није било мртвијех: по брдима, Аолинама, вртовима и поьима; све је бимо препуно мртвијех тела. Неки су бими растављени и одвођени у туђу земьу, брат оА брата, син оА оца, мајка од сина. Свуда се могао чути горки плач и ридање. Јао и тешко нама, говораху, боље би нам било, да нас је све примио један гроб, него што нас одводе у туђу земљу - и пмакаху и јаукаху један за другим. И

\footnotetext{
${ }^{5}$ Запис у рукописној књизи манастира Крушедола из 1593. године.

${ }^{6}$ Запис у рукописном минеју манастира Сретења, округ Руднички, из 1595. године.
} 
запустје та земьа сасвим" (Слијепчевић 2002: 324-325; исто и: Стојановић 1982: 6p. 8947).

Један монах 1690. године оставња запис о расељењу и запуштењу српске земье: „В тои же рати бист великое пленение и разселение народу христианском, и запуштение всеи србскои земли: монастирем, варошам и селам опустевшим, неким совсем сгоревшим. Такожде и нашем монастиру Раваници в Сербии коначное запустение бист" (Стојановић 1982: бр. 52868).

Страдалне ријечи о запуштењу хришћанских земања, а највише српских, у вријеме Великог бечког рата, налазе се у јеАној рукописној књизи насталој 1696. године у манастиру Ораховици, у Славонији: „И таква скрб, бијеАа же и нужда је бима, каква није бима никада, нити су икада описани, нити су се десими такви ратови. И запуштење би у земьама угарској, српској, бугарској и херцеговској. И до самога Солуна и Константина Града христијаном велика, а Србњем же највећа бијеАа би; глад и плењење, и мјестима остављање, и многима манастирима коначно запуштење, и светим многим моштима из мје́ста̄ својих преношење, Аругима же и сагорење, и светим и свештеним сасудима и одежАама оА поганских и скврних рука разграбње́ње! Јао, оци и браћо, јао каква туга! Најпослије, убоги иноци, који се у то вријеме скиташе од мјеста Ао мјеста, у земьама угарској и немецкој, оА тих Немцова и оА Угрова, и оА самих њихових христијана, прогоњени и хуњени бијаху и с мржњом називани одметницима!" (Стојановић 1982: бр. 2015).

\section{Свједочења}

О тим страшним страдањима пореА монашких записа говоре и свједоче и епске пјесме, као што је она „Када Турци Босну заузеше”, коју је бихаћки прота Коста Ковачевић, у чканку о историји манастира Гомеме, записао 1888. године и објавио у „Аабро-босанском Источнику”:

Када Турци Босну заузеше

По њој зукум чинити почеше,

Обарају свете манастире,

Руше, пале цркве и олтаре

Па подижу бијеме мунаре.

Понајприје, побратиме Араги,

Уватише старца игумана,

${ }^{7}$ Запис у рукописном минеју манастира Св. Павца у Св. Гори, из 1601. године.

${ }^{8}$ Запис у рукописној књизи манастира Шишатовца из 1690. године. 
Младенко С. Саџак

По имену оца Јеремију,

Из ГАоговца код Варцар-вакуфа,

Па га жива на колац набише,

А манастир са земьом заравнише;

Упамише Озрен цркву бијелу,

На сред Босне земье ојађене;

Похараше Моштаницу красну,

Бцизу Саве, близу воде мадне;

Хрмањ тврди код Вакуфа града,

Упалише, огњем сажегоше,

Камуђере у њем поваташе

И по реАом свију исјекоше;

А Гомеку пусту затекоше,

У њој свете ствари оскврнуше...

(Ковачевић 1888: 157)

Поменуто питање о разграничењу између историје и књижевности може се актуелизовати и поводом ове пјесме; наиме, епска пјесма, првобитно на исти начин као и историјски документ или монашки запис, имаха је функцију Аа сачува, да запамти одређене историјске догађаје, мичности и дешавања. Међутим, када поједини запис или пјесма престају да буду само вијест која свједочи и чува од заборава, тј. када уз свјесне ауторове намјере, исказане посебним језиком, уз употребу специфичних и сврховитих стилских среАстава и поступака, постају носиоци и одређене емоције, Араме, идеје или рефлексије, када се у њима деси промишьање човјека, историје ими судбине, тада они из сфере историје прелазе и постају и дио планете књижевности.

Тако ће свијетла визија кнеза Аазара, о његовој будућој цркви Раваници („УАарићу темељ од олова, / Па ћу цркви саградити платна, / Саградићу од сребра бијела, / Покрићу је жеженијем зматом, / Поднизати Аробнијем бисером, / Попуњати драгијем камењем..."), бити нарушена (затамниће се) због опште опасности од доласка Турака и настанка „пошьедњих времена”, а које преАсказује војвода Мимош Обимић. У овој пјесми јеАан од наших највећих јунака добија сасвим нову улогу - познајући и прошиост („књиге цароставне”) и садашњост, Обимић предвиђа и будућност и „свој српској господи” Ааје наук:

Већ чу ми ме славни кнез- $\Lambda$ азаре!

Аа копамо мермера камена, 
И Турци ће царство преузети

И наше ће залужбине служит'

ОА вијека Ао суда Божјега:

„ОА камена ником ни камена!"

(Караџић 1985 II: 147-149)

\section{Трансформације}

Трансформације историјских догађаја, који своје прво (временски најраније) мјесто налазе у скривеним забиьешкама и хроничарским записима анонимних писара и манастираца, а потом премазе у књижевне (литерарне) текстове, свакако заслужују пажњу савремене филологије.

У историјској приповијеци Крв за род Јакова Игњатовића тематизован је читав низ Аруштвених појава из турског времена: исламизација, вољна и невољна, безакоње па̂ша̄ потурица, отмица Ајевојака, насиье наА хришћанском рајом, веза између грчких владика и турских власти, купопродаја свештеничких чинова, опустошење манастира (Раванице), појава хајдучије, ратни походи турске војске и јаничара, повратак потурчењака на хришћанство... „Јадна Босно, шта си препатима!", пишчев јаук на почетку ове приповијетке могао би бити наднаслов за многа дјела из наше старије и новије књижевности (Игњатовић 1988: 134). ОА Сарајлије и Стерије преко Бубише и Сремца до Кочића и Андрића, многи писци, неријетко и плодотворно, преузимали су „страдалничку" грађу и из наших старих записа, хроника, народних пјесама и преАања.

ЈеАан оА писаних извора који увјерьиво свједочи о одвођењу хришћанске Ајеце у јаничаре (премда су и у народном памћењу остала сјећања на тај немими данак) јесте књига Константина Михаимовића Јаничарове успомене или Турска хроника, у којој аутор приповијеАа како је и са̂м био жртва тог данка y крви. Приказујући Турску, која узима и насимно исламизује своје поробњене поданике, кроз алегоријску слику сланог мора у које се улијевају све слатке воде (а „онда, када у море уђу и помешају се с морском водом, сва доброта и сласт њихова се губи и постају као и друга морска вода - густа и слана"), писац хронике закьучује: „И то се дешава много пута годишње: десет до Авадесет хиљада хришћана доводе међу поганике, па помешавши се, сви се покваре као и речне воде у мору, јер напустивши веру своју, поганску примају. И каА тако пређу гори бивају такви хришћани него прави поганици. И тако све то 
Младенко С. Саџак

служи њиховом размножавању: док јеАни ислужују, Аруги су ислужики и Аруге доводе..." (Михаимовић 1959: 145; XLVII глава, О турском размножавағу).

Једну причу из ове хронике, о томе како је султан МехмеА II Освајач, послије освајања богатог и многољудног града Новог Брда (1455), узео „између робьа осам Србаља, потурчене дјеце, да га служе као слуге”, а они се Аоговоре Аа га убију, обрадио је Стеван Сремац у приповијеци Заборављени Обилићи. Страдања тих младића послије издајства једног од њих, слике њихових обезглавьених мешева на некој пустој поьани у околини Аренопоьа, тајно поноћно опијело које је одржао Константин Михаицовић са неколико пријатеља, такође Срба јаничара, и сахрањивање тих нових мученика крај неког опустјелог црквишта, једна је од ријетких забиьежених трагичних историја које су дошле до нас. „Паде и Србија, и шумовита Босна, и кршевита земьа Херцеговина. Биједа притисну земье те. И симно робље језика и племена [српског] гоњаше се и продаваше по трговима царства турскога; продаваше се у бесцјен, толико га много бјеше" (Сремац 1977: 419).

Та појединачна мучеништва, од којих су она безимена и незабиьежена неупоредиво бројнија оА знаних и описаних, велика су тема и велики изазов наше фимологије, историје и културе сјећања.

Из прошлости једног оА највећих српских манастира у Босни, Моштанице, сазнаје се да је он у шест или седам вијекова постојања најмање десет пута био рушен и пањен (аАи и Аа је увијек изнова био подизан и обнавьан). ОА многих хришћанских страдацника, који су бими везани за манастир, издвајају се Авојица: свети мученик Теодор (САадић) Комоговински, којег Српска православна црква обиьежава заједно са Теодором Тироном, на Теодорову суботу (у прву суботу Васкршњег поста), те преподобни мученик Ђакон Авакум, који се обиьежава 30. децембра, заједно са Пајсијем (Ристовићем), игуманом манастира Трнове, са којим је и био погубњен на београдској Стамбол-капији у вријеме Хаџи Проданове буне (1814).

${ }^{9}$ Први превод овог дјела на српски језик изашао је у Београду 1865 . године, када га је Јанко Шафарик превео са чешког и штампао у Гласнику Српског ученог друштва, књ. XVIII, стр. 25-188, са насловом: „Мијаима Константиновића, Србина из Острвице, Историја или ьетописи турски, списани око године 1490”, док је у самоме тексту наслов тог дјела био: „Турска историја ими кроника, верно и истинито списана од неког Србина ими Бошњака, званог Мијаимо Константинов из Островице, ког су Турци негда заробили и међ јаничаре дали”. Издање које се овдје користи приредио је Ђорђе Живановић (Српска академија наука, Споменик CVII, ОАењење Аруштвених наука, Нова серија 9, Београд 1959). 
године освојима Аубицу. Послије пропасти те тзв. Ааудонове војне, Турци су из освете убили око 150 ьуди, а јеромонаха Теодора су живог спалими испреА манастира. Његове мошти биме су чуване у Моштаници, а потом су пренесене у манастир Комоговину, сјеверно оА Костајнице, који су јеАан вијек раније и основали избјегли моштанички калуђери. ${ }^{10}$ Тим моштима је народ Крајине и Баније долазио на покмоњење, био је створен својеврсни култ и свети Теодор (САадић) је из историје на неки начин прешао у народно предање, у којем се и данас помиње (а често и поистовјећује са Св. Теодором Тироном).

Мученичко страдање и јуначка смрт Ђакона Авакума, које је описао Сима Мимутиновић Сарајмија у Историји Србије 1813-1815 (настамој 1837. године), учинили су, међутим, да он из историје пређе и у књижевност.

Сарајлија је забиьежио и бесмртне стихове које је овај ммадић, „Аиван и дичан као Апомон”, пјевао уочи свог погубњења: „Ао неколико дана послије Пајсија смерти поведу и њега на губимиште, упртивши му на раме и његов заоштрен колац, па су га све понајлак до мјеста водећи нудили сви редом и грозама и обећањима свакојакима, скмањајући га да се потурчи и да тако мкаА и кијеп не погине узалуд... На то би он њиј упиткивао: А умиру ми и Турци? Па смијешећи се, ни оАговора им не шчекавши, запјевао би јуначки серпским гласом овако:

Нејма вјере боље ол ришћанске!

Серб је Ристов, радује се смерти,

Божиј страшни суд и Турке чека,

па ви чин'те што је вама Араго!

Скоро ћете Турци долијати,

Бог вам јемац и Божија правда!"

А на молбе и његове тужне мајке, Аа се потурчи а да остане жив, он јој „радо и весело пјесном зафали и одговори:

Мајко моја, на м^’јеку ти хваца!

Брзо ћеш се обрадоват сину,

Аок преА мице Бога изађемо;

Смрт избавьа оА свакије б’јеАа.

Цват прољећа по зими се јавња,

БАаго сваком ко раније умре,

О мање је муке и гријеха,

\footnotetext{
${ }^{10}$ Касније су његове мошти (једна несагорива рука) биме чуване у цркви у Костајници, потом у Саборној цркви у Кармовцу па опет у Костајници, а траг им се изгубио у погрому Срба у Хрватској 1995. године.
} 
Младенко С. Саџак

Па што дадне спас и вјера коме,

А још има браће на свијету!”

„Исти се Турци”, наставьа Сарајлија, „удиве толикој миадића једнога неустрашности и великодушију, и чудно тврдој вјери, те му се смикују, Аа му прије ножем (јатаганом) срце прободу, па га на колац мртва натну и усправе посадивши га међу остаце на своје мјесто украј пута к Теразији пошавши иза Стамбол-капије варошке" (Мимутиновић 2016: 300-301).

\section{Рушење и изградња цркава}

Уз та мучеништва и народна страдања, отимање дјеце, гладне године, безакоња, исламизацију (Аа помемемо и унијаћења и покатоличења), укратко - уз све те пошасти и невоље, нашем колективном сјећању и преАставама о турском добу припадају и рушења и скрнављења цркава.

Најпознатије страдање те врсте у византијском свијету био је паА Цариграда 1453. године и, као зма слика која га је пратила - улазак Турака на коњима у највећу хришћанску богомољу на свијету, у цркву Аја Софију. О том догађају много се говоримо и писало у Европи и код нас, а то понижење хришћанства оставицо је трага и у нашем простонародном црквеном градитеьству. Наиме, мале сеоске цркве брвнаре, које су у вијековима нашег робовања замјењивале некадашње камене грађевине, имаце су ниска умазна врата, како би и „трикмети Агарјани”, ако би хтјели ући у њих, морали сјахати са коња и погнути се - приклонити се земьи.

Вратимо се Аја Софији: њен најьепши опис у српској књижевности 19. вијека настао је „по опису који је дао италијански путописац ЕАмонд Ае Амичис у свој књизи Цариград", а чији је превод коА нас урадио Стјепан Митров Бубиша у Причағима Вука Аојчевића ${ }^{11}$. Међутим, Фубиша је отишао дање од тога - он је том опису додао своје виђење Араматичних догађаја по самом паду Константиновог града: слику народа скцоњеног у цркву, описе њихових молитви, надања и плачева, потом је приказао сцену уласка „турске хордије” у цркву, узвјерених „покоља, грабежи и блудства”, као и султана и његове пратње Аок на коњима умазе у Јасофију. Његов је и завршни додатак тог мајсторског 31. причаға (Ако јемука трпјети, није паметовати), у којем се даје једна алегоријска прича, о цариградском влаАици који се испреА крвожеАних Турака

${ }^{11}$ „Овај опис Аја Софије Фубиша је углавном начинио по опису који је дао италијански путописац ЕАмона де Амичис у свој књизи Цариград” (Бубиша 1955: 211; фуснота, примједба Микије Станића, приређивача). 
скцања иза неких врата „која се за њим затворе самоковнијем зидом. Турци су читав Аан млатили у тај зиА прьем, ћускијом и топузом, Аок их умори и свлада труд. Бадава су се изредими цариградски ковачи и гоге, зид под тешкијем ударцима гвоздена оруђа остаде зАрав, и остати ће док год устраје турски бич, Аок се оцкврњени храм не поврати служби Бога живога. Тада ће изаћи узидани старац, весео и бцагообразан, прави мик Божијег мимосрђа... и тај дан ће засјати Костадинову граду зора новог доба.

Није нама дано знати час и годину каА ће се то догодити, јемац нам је Божја премудрост, у чије је име посвећен ови храм. ${ }^{12}$ У толико тјешимо се вјером и ухвањем, а разабирајмо се причањем и памћењем, јер ако је мука трпјети, није паметовати" (Ьубиша 1955: 214).

У српском књижевном насьеђу ова амегорија асоцира на пјесме Наход Cuмеун те Цар Константин и ђаче самоуче (Караџић 1985 II: 55, 72) ${ }^{13}$, а потом и на низ пјесама о дјевојачком грађену цркава.

Историјски, мотив забране грађења цркава у Отоманском царству (као и у Аругим исламским државама) има своју основу у збирци закона коју је под називом „Канун-и-раја” за хришћане и Јевреје прописао калиф Омар ац Катаб у Аамаску 635. године. Између остацих забрана, хришћани и Јевреји, каже се у том канону, у покореним земьама не смију подизати манастире и испоснице, као ни своје цркве; изван својих кућа не смију јавно носити крст ни своје свето писмо; у својим кућама не смију гласно ни снажно звонити; у њима (могу) само полугласно да пјевају; смију само тихо Аа се моле за покојнике, итА. (Анарић 1995).

Описујући стање хришћана у Босни у првој половини 19. вијека, Аакле пред крај турске вмадавине, Иван Фрањо Јукић на крају књиге Земљопис и повијестница Босне (1851) казује: „У Босни крстјани цркву нову начинити, ол стару поправити, тко би само о тому споменуо, наопако би му бимо; већ јаАници, голе обријане главе на Авору по снијегу слишају молитву; Аоисто се човјеку гледајући, кожа јежи” (Јукић 1851).

У тој и таквој стварности, без државе и вцастеле, без закона и правде, народу и свештенству преостала је само вјера у спасење и нада у неки бољи и ьепши свијет. А како се тај свијет није могао десити у стварности, остајала је могућност - у пјесми. Као, на примјер, У Јанини, високој планини, у којој Ајевојка-неимар гради јеАну оА наших најьепших поетских цркава:

\footnotetext{
${ }^{12}$ „Софија на грчком језику значи: мудрост” (прим. С. М. Бубише).

${ }^{13}$ Свакако треба поменути и преАање о смрти Марка Крањевића, по којем он није умро, него су и он и Шарац у некаквој пећини, у којој и сад живе.
} 
Младенко С. Саџак

У Јанини, високој планини,

Сама сједи иијепа дјевојка,

Сама сједи, а сама бесједи:

„Аа с' не бојим цара ни везира,

Бијелу бих цркву начинима.

Накитила Арагијем камењем,

Поднизала ситнијем бисером,

3цатне греде, сребрне рогове,

А покрима кровом позцаћеним,

Аа се сија у планини црква!"

Она мисли, то нико не чује,

A^’ је чују пашине демије...

(Карановић 1990: 192-194)

Нестварне ьепоте је и црква у сьедећој пјесми:

Фалима се фаьена дјевојка:

„Ситне ћ' зв ' језде с неба сабајат' 14

и онога јаснога мјесеца.

ОА зв ' језАа ћу цркву саградити,

од мјесеца цркви б' јела врата.

Очима ћу иконе писати,

по уму ћу метургију пјети.

На коњицу хоћу цркви доћи,

с коња копьем цркву отварати."

Што је рекла фаљена дјевојка,

што је рекца све је сатворима...

То се чудо чак до цара чуло...

(Ерлагенски рукопис 1987: 90)

Необичне грађе је и црква која се гради у пјесми Цар и дјевојка, у Првој књизи Вукових Српских народних пјесама, у групи у којој су „пјесме особито митологичке":

Фалима се мепота Аевојка:

Прести нећу, а не умем вести,

Баби нећу чувати говеда;

Насред горе саградићу цркву,

${ }^{14}$ сабајат(и), свр. - урадити нешто бајно (од бајати - тајанственим ријечима чинити чудеса), чаробно, заносно, красно. 
Темељ ћу јој од мермера камена,

А греде ћу арво шимширово,

А слеме ћу арво тамбурово."

Та се фала чак до цара чула...

(Караџић 1985 I: 155)

За њима нимало не заостаје ни визија цркве коју видимо у пјесми Цар $и$ Анища Ђевојка:

Ружу бере Аница ђевојка,

Ружу бере, ш њом се разговара:

„Аијепа ти си, румена ружице!

Ја сам ьепша Аница ђевојка;

Јошт Аа смијем оА цара мојега,

Све бих поље ружом посијала,

А гору бих свином загрнула,

На сред поља цркву саградила,

И у цркву дванаест олтара,

И ставила дванаест калуђера,

Сваки данак у цркву одила,

И на олтар по дукат метала,

Све за душу оца и матере".

Мисли Ана, нико је не чује,

Зачуме је Ав' је цареве слуге...

(Караџић 1898: 625-627)

Тако је народни пјевач, насупрот турске симе и терора, господства и богатства, градио своје свијетле нестварне грађевине, али не оА камена и олова, као они који влаАају, него оА понижења и оАрицања, од жеља и ината, оА вјере и наде. Намјерно смо оставьали стихове који слиједе послије описа тих мијепих грађевина, јер су иза тих визија као зајеАнички наставак редовито слиједиме препреке - необичне неимарке у овим пјесмама имаме су ими забране ими понуде да пређу на ислам и да постану везирове/цареве ьубе. Како оне нису пристајале на то, бивале су или нападане симном војском (коју су, уз помоћ вишњих сима, побјеђивале), или су биме затваране „у тамнице кмете”.

У овој Аругој, страдалничко в варијанти, послије времена дугог утамничања, цареве слуге које Аолазе Аа „изваде кости Ајевојачке, Аа се јарка огрију сунашца”, имају шта да виде: 
Младенко С. Саџак

КаА отвори на тамници врата,

ПреА очима сијну му тамница,

У тамници оА зАата синија,

На синији свака ђаконија,

КоА синије оА зАата столица,

На столици света Богомајка,

Код ње сједи мијепа дјевојка...

(Карановић 1990: 194)

Апстрахујући ове варијантне пјесме о изградњи хришћанских богомоља и страдања због тога, Аолази се до заједничког мјеста - ове се дјевојке, као носиоци вјере и постојаности, посвећују и премазе у Царство небеско.

\section{Царство небеско}

Враћамо се почетном питању: гАје је граница између историјских чињеница и књижевних текстова; када се и како, по којим мјерилима, може утврдити да одређени записи припадају историјским изворима или књижевности?

Подсјетимо се на стару грчку реторичку тријаду, о врстама говорења, а коју чине епос, Аогос и митос: епос је говор историје, то је прича у којој се налази појеАиначни примјер из стварности; логос је говор фимозофије у коме се Аају опште/универзалне истине; а митос је књижевни говор, у којем се у појединачним причама дају опште и универзалне истине. По томе разликовању, дакле, прича о страдању Ђакона Авакума јесте митос - то је нова прича о Христовом страдању, о младићу које је све оставио - мајку, живот и овоземаљски свијет, и који се одмучио за Царство небеско.

Царству небеском припадају и дјевојке које се нису хтјеле потурчити, него су заслужиме, као и многе друге, незнане и безимене мученице, и многи страАалници, своје насеље у Рају, у друштву и заједничарењу са Богородицом. И пјесме о њима преАставьају потраге за вишим спознајама, тежње за, што каже Његош, Царством поезије.

Такав је и Ьубишин вмадика затворен у страдамној цркви Аја Софији, који чека ослобођење Цариграда, дан када ће... „у Костадинову граду засјати зора новог доба". Такви су и многи други хришћански светитеьи, подвизници и мученици, од Св. Саве до Св. Теодора и Св. Авакума... Сва њихова страдања каА собом почну да носе истине или спознаје о нечем изван себе, о нечем идејно вишем, трајнијем и општијем, онда можемо рећи да је историјска чињеница постала и/ими дијелом прешла у књижевну, а да се историја (као Аокумент, акт, 
податак) трансформисаха у књижевност (нову стварност, обновьени свијет, митос, који је спој појединачног и општег, пролазног и универзалног).

Чини се да је, у том кьучу посматрана, цијела наша кцасична књижевност, и она која је настала и која се проносица у народу усменим путем, и она писана, од Св. Саве преко Његоша, па до Матавуьа, Кочића и Андрића, да је сва она бима посвећена и усмјерена ка Царству небеском.

Тако се и српски народ, и мишьу и осјећањем, и напором и подвигом, и ријечју и дјелом, сврстао у хришћанску цивилизацију.

\section{Извори}

1. Ерлангенски рукопис (1987), зборник старих српскохрватских народних песама, Никшић.

2. Игњатовић, Јаков (1988), Крв зарод, у: ОАабрана дема Јакова Игњатовића, књига VII (Романтичарско-историјске приповетке), Нови СаА - Приштина: Матица српска - Јединство.

3. Караџић, Вук Стефановић (1898), Пета књига, у којој су разцичне женске пјесме, БеограА.

4. Караџић, Вук Стефановић (1985 I), Српске народне пјесме I, Аема Вука Караџића, БеограА: Просвета-Нолит.

5. Караџић, Вук Стефановић (1985 II), Српске народне пјесме II, Аема Вука Караџића, БеограА: Просвета-Нолит, 155.

6. Бубиша, Стјепан Митров (1955), Причата Вука, Аојчевића, БеограА: РаА.

7. Михаиловић, Константин (1959), Јаничарове успомене или Турска хроника, БеограА: Српска академија наука, ОАењење друштвених наука.

8. Стојановић, Бубомир (1982), Стари српски записи и натписи, књиге 1-6 (фототипско издање), БеограА - Нови СаА: САНУ - Народна библиотека Србије - Матица Српска. (Напомена: уз ово издање не наводи се број књиге и странице, него број наведеног записа.)

9. Сремац, Стеван (1977), Заборављени Обилићи, у: Сабрана дела Стевана Сремца, књ. пета (Из книга староставних), Београд: Просвета.

\section{Митература}

1. Анарић, Иво (1995), Развој духовног живота у Босни под утичајем турске владавине, Бања $\Lambda$ уа.

2. Јовановић, Герман (1891), „Воведенски манастир Гомионица”, Аабро-босански Источник за год. 1891. (Преузето из књиге Први шематизам православне српске 
Младенко С. Саџак

митрополије Бањалучко-Бихаћке за годину 1901, Бања Аука: књижара С. Угреновића.)

3. Јукић, Фрањо Иван (1851), Земьопис и повијестница Босне, Загреб.

4. Карановић, Зоја (1990), Народне песме у „Даници”, Нови СаА - БеограА: Матица српска - Институт за књижевност и уметност.

5. Ковачевић, Коста (1888), „Нешто о манастиру Гомеми”, Аабро-босански Источник, Аист за црквено-просвјетне потребе српско-православног свештенства у Босни и Херцеговини, бр. 4 (19), год. II, априм 1888. године, Сарајево, 157-158.

6. Мимутиновић, Сима Сарајлија (2016), Историја Сербије (одломщи), Аесет векова српске књижевности, књига 26, Нови СаА: Издавачки центар Матице српске.

7. Панић-Суреп, МимораА (1963), Кад суживи завидели мртвима, БеограА: Нолит.

8. Слијепчевић, Ђоко (2002), Историја српске православне иркве I-III, БеограА.

9. Чубриловић, Васа (1960), „Историја српске православне цркве под Турцима оА 15. до 19. вијека”, зборник Филозофског факултета, књ. V-1, Београд.

\section{СЕРБСКИЙ НАРОА, ЦЕРКОВЬ И ГОСУААРСТВО В ТУРЕЦКИЙ ПЕРИОА (ИСТОРИЯ, ЗАПИСИ, АИТЕРАТУРА)}

\section{Резюме}

Основная цель этой работы состаялась в том, чтобы классифицировать и представить главные темы сербского страдания в так называемый турецкий период, а именно: мученические судьбы отдельных $ю$ юй, страдание народа (взятие детей в рабство, исламизация и Ар.), разрушение церквей и монастырей и, в конце концов, расселение населения и опустошение страны.

ОАнако, специфический предметный материац, а также разАичные источники, на основе которых эта тема рассматривацась, наложили еще одну цель исследования: установить отношения (а также возможные законы трансформации) между историческими событиями и фактами, отрывочными монашескими записями и редкими хрониками о них, а затем и митературными текстами / митературными произведениями, создаваемыми по их образцу. 